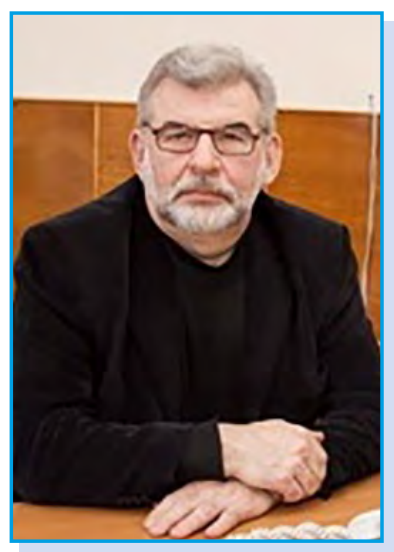

Юрій Жук - доктор педагогічних наук, доцент, завідувач відділу моніторингу та оцінювання якості загальної середньої освіти Інституту педагогіки НАПН України, м. Київ, Україна.

Коло наукових інтересів: педагогічна кваліметрія, середовища навчання.

\title{
zhukyrij@gmail.com
}

https://orcid.org/0000-0002-6932-2484

Антоніна Гривко кандидат педагогічних наук, старший дослідник, старший науковий співробітник відділу моніторингу та оцінювання якості загальної середньої освіти Інституту педагогіки НАПН України, м. Київ, Україна.

Коло наукових інтересів: теорія і методика оцінювання результатів навчання, моніторинг якості освіти, тестові технології оцінювання, медійно-інформаційна грамотність.

av.hryvko@gmail.com

iD https://orcid.org/0000-0001-9460-4777
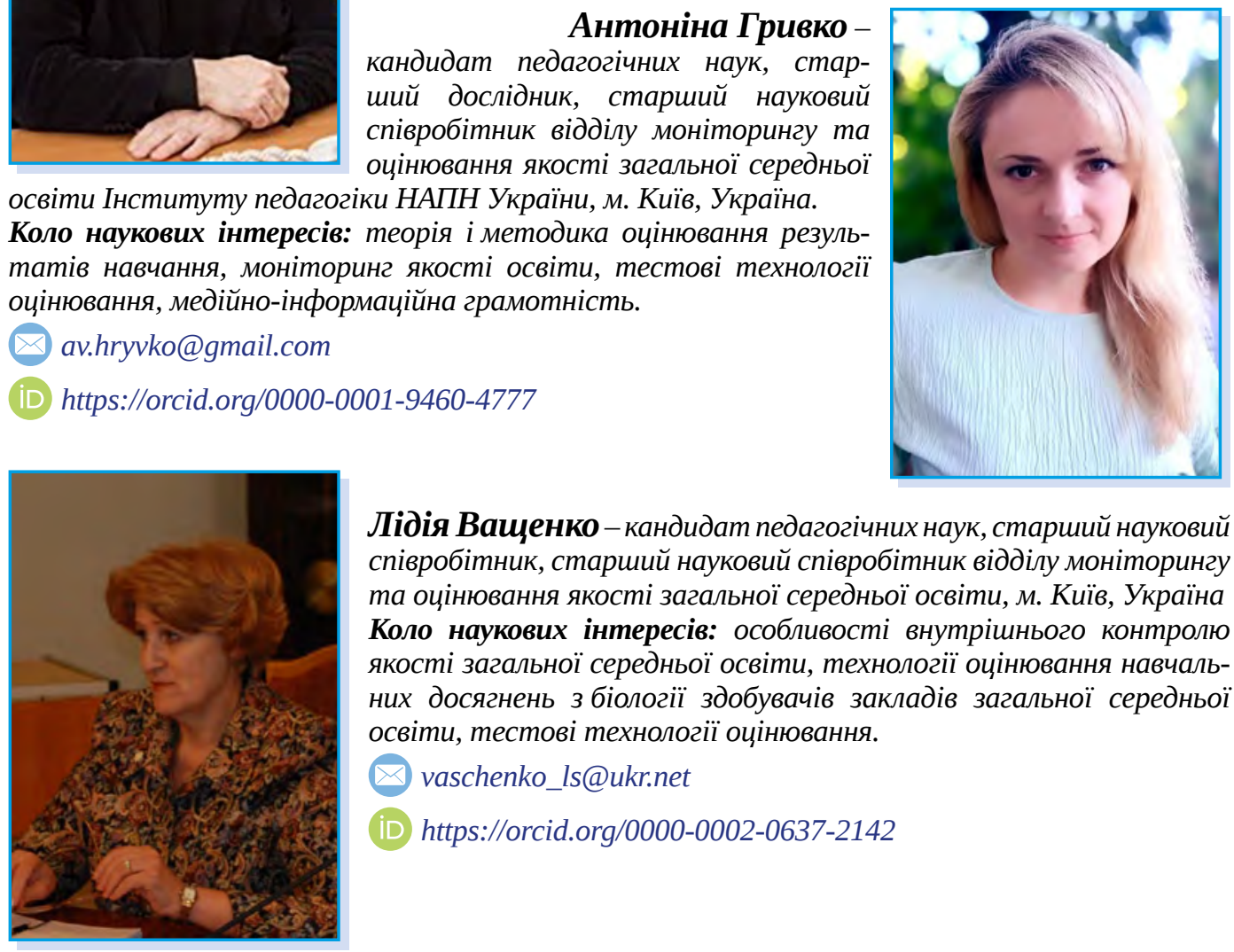

Лідія Ващенко - кандидат педагогічних наук, старший науковий співробітник, старший науковий співробітник відділу моніторингу та оцінювання якості загальної середньої освіти, м. Київ, Україна Коло наукових інтересів: особливості внутрішнього контролю якості загальної середньої освіти, технології оцінювання навчальних досягнень з біології здобувачів закладів загальної середньої освіти, тестові технології оцінювання.

vaschenko_ls@ukr.net

https://orcid.org/0000-0002-0637-2142

УДК 37.014.3:371.263/261

https://doi.org/10.32405/2411-1317-2021-4-96-105

\section{ДОСЛІДЖЕННЯ ОСОБИСТІСНОГО СТАВЛЕННЯ ВЧИТЕЛІВ ДО ПОТОЧНОГО ТА ПІДСУМКОВОГО ОЦІНЮВАННЯ ЯК УМОВИ ВИБОРУ СТРАТЕГІЙ КОНТРОЛЬНО-ОЦІНЮВАЛЬНОЇ ДІЯЛЬНОСТІ}

У статті розглянуто особливості визначення вчителями об’єктивності поточного та підсумкового оцінювання результатів навчальної діяльності учнів як однієї з умов вибору стратегії 
контрольно-оцінювальної діяльності. За результатами опитування визначено узагальнене для різних груп респондентів значення об'єктивності відображення у поточній і підсумковій оцінках знань, умінь, навичок, компетентностей, ставлення учнів до предмету, а також побудовано й проаналізовано моделі ментальних образів «поточна оцінка» і «підсумкова оцінка», які склалися у вчителів із різним досвідом роботи. Подальші дослідження можуть бути пов’язані з вивченням питань щодо використання педагогами результатів поточного оцінювання для прийняття рішень щодо подальших стратегій навчальної діяльності.

Ключові слова: поточне оцінювання; підсумкове оцінювання; формувальне оцінювання; об’єктивність оцінювання; результати навчання.

Постановка проблеми в загальному вигляді та ії зв’язок 3 важливими науковими та науково-практичними завданнями. Практика свідчить про те, що навчання й оцінювання його результатів $€$ взаємопов'язаними та взаємозалежними процесами. В умовах стандарт-орієнтованої освітньої політики цілеспрямований процес навчання неможливий без оцінювання результатів педагогічної діяльності, які здебільшого виявляються визначенням відмінностей шляхом зіставлення рівня навчальних досягнень учнів та вимог стандарту (критеріальне оцінювання).

Згідно з традиційним розумінням, оцінювання може здійснюватися як у процесі (поточне), так і на різних рубіжних етапах (підсумкове) навчання. В останньому разі ці відмінності з'ясувати найпростіше. Водночас за умови негативних результатів рубіжного оцінювання виправити ситуацію зазвичай неможливо. В умовах оцінювання проміжних результатів безпосередньо в процесі навчання (поточне оцінювання) 3'являється можливість виправлення недоліків у формуванні знаннєвих і деяких особистісних якостей учнів. Саме ця особливість поточного оцінювання вплинула на виокремлення в його структурі формувального оцінювання, яке у зв'язку з досягненнями когнітивної науки (розширення концепції аспектів навчання, які $є$ найбільш важливими для оцінювання) та педагогічних вимірювань (розширення можливостей інтерпретації результатів навчальної діяльності учнів) у межах гуманістичної парадигми особистісно-орієнтованого навчання стало центральним поняттям (трендом) у сучасних підходах до оцінювання. Зважаючи на те, що оцінювання є систематичним процесом, спрямованим на з'ясування того, що учні знають і що вони можуть робити самостійно й у групі відповідно до свого оптимального розвитку і цілей навчальної програми, автори багатьох публікацій стверджують, що застосування формувального оцінювання значно розширює спектр характеристик, які мають бути враховані у процесі навчання. Іншою особливістю формувального оцінювання є його спрямованість на корегування індивідуальних векторів навчання учнів, особливостей викладання предмета вчителем та взаємодії учасників навчального процесу (виявлення та усунення недоліків під час навчання). Думка про те, що формувальною оцінка стає лише тоді, коли вчитель використовує інформацію про досягнення учня для прийняття рішень щодо того, як адаптувати навчання до його потреб (Pellegrino et al, 2001, с. 229), робить можливими висновки: 1) формувальне оцінювання може розглядатися як модернізована форма поточного оцінювання в аспекті розширення його цілей, функцій і завдань (вдосконалення процесу і покращення результатів навчання); 2) у зв’язку з наявністю емпіричних доказів про те, що учителі не завжди вносять зміни в підходи до навчання та методику викладання предмета, базуючись на результатах оцінювання, щоб покращити навчальні досягнення учнів (Lange, 2014, с. 98), іншою формою поточного оцінювання можна умовно визначити констатувальне (облікове) оцінювання (фіксування навчальних досягнень учнів як проміжних станів засвоєння ними елементів освітньої програми у процесі навчання; часто розглядається як частина системи підзвітності). Попри дещо різні функції формувального та облікового оцінювання, вони є взаємопов'язаними та складають цілісну систему поточного оцінювання (беручи до уваги особливості сучасної системи оцінювання в закладах середньої освіти України), яке впливає на результати підсумкового оцінювання.

По суті поточне й підсумкове оцінювання грунтуються, відповідно, на диференційованій та інтегративній інформації про стан рівня навчальних досягнень учнів, завдяки якій у всіх учас- 
ників освітнього процесу з'являється можливість зробити певні висновки і вжити адекватних заходів. При цьому результати оцінювання в кожному разі завжди грунтуються на судженнях вчителя або учня щодо визначення загальної їх (результатів оцінювання) цінності. Однією з найважливіших цінностей оцінювання, беручи до уваги подальше прийняття відповідних рішень, $\epsilon$ впевненість учасників освітнього процесу в його об’єктивності. Свідченням цього є велика кількість праць, присвячених вивченню чинників впливу на об’єктивність педагогічного контролю та оцінювання (праці Є. О. Голубєвої (Голубева, 1993), В. І. Зикова (Зыков, 1971) та ін.), питанню залежності об’єктивності контролю та оцінювання від рівня стереотипізації оцінювальної діяльності педагогів (праці В.Ф. Петренка (Петренко, 1986), А. О. Реан (Реан, 1994) та ін.), умовам об’ єктивності контролю та оцінювання (Є.Й. Перовський (Перовский, 1960)) тощо).

У зв’язку із запровадженням компетентнісного підходу до навчання, розширюється спектр результатів навчальної діяльності учнів, які характеризують рівень сформованості в учнів предметних і ключових компетентностей, що зумовлює необхідність чіткого визначення того, що має оцінюватись у процесі та на завершальних етапах навчання. У традиційній системі поточного оцінювання навчальних досягнень здобувачів середньої освіти вчитель є носієм сукупності оцінок - якостей і властивостей, відношень, дій, поведінки, навчальної діяльності, успішності, знань, умінь учнів. Формально оцінюванню та фіксуванню його результатів підлягають лише знання та вміння учнів, але результати поточного оцінювання завжди містять суб'єктивний елемент, зумовлений формуванням у вчителя суджень щодо особистісних характеристик кожного учня щодо його старанності, інтелектуальних можливостей, наполегливості, уваги тощо, для об’єктивного вимірювання яких необхідні засоби, які містять наперед визначені одиниці вимірювання (система критеріїв, шкала вимірювання) та відповідні інструменти оцінювання. Їх відсутність є одним із чинників суб’єктивізму оцінювання.

У пропонованій статті здійснено спробу, спираючись на експериментальні відомості, з’ясувати особистісне ставлення вчителів до поточного й підсумкового (рубіжного) оцінювання, оскільки таке ставлення визначає вибір педагогом видів та інструментів оцінювання, можливість їх модернізації (в тому числі і в напрямі формувального оцінювання), а також правильність прийняття відповідних педагогічних рішень за результатами оцінювання.

Аналіз останніх досліджень та публікацій 3 проблеми. Питання оцінювання навчальних досягнень учнів у педагогічній літературі часто розглядається у зв’язку з проблемою забезпечення об’єктивності контрольно-оцінювальної діяльності педагогів, пошуком об’єктивних методів і технологій оцінювання (наприклад, вивчення особливостей тестових технологій оцінювання компетентнісних результатів навчання - Ляшенко та ін. (2014, 2017)); вивченням питання використання вчителями результатів оцінювання для коригування методики навчання (Lange, 2014), ефективність внутрішньошкільного оцінювання (Gomez, (2017), дослідженням уявлень учителів про цінності оцінювання та професійної оцінювальної грамотності (Deneen, 2019) тощо. У більшості таких праць вивчаються чинники, які впливають як на результати оцінювання, так і на педагогічну практику. Водночас дослідження умов, за яких здійснюється такий вплив (у тому числі й особистісне ставлення вчителів до проблеми рівня об’єктивності поточного та підсумкового оцінювання), допоможе визначити напрями вдосконалення методичного забезпечення модернізації системи оцінювання навчальних досягнень здобувачів загальної середньої освіти.

Мета дослідження полягає у вивченні питання особистісного ставлення чителів до поточної та підсумкової оцінки результатів навчальної діяльності здобувачів загальної середньої освіти як однієї з умов вибору стратегій контрольно-оцінювальної діяльності.

Методика дослідження. Для вивчення поглядів учителів на проблему об’єктивності оцінювання навчальних досягнень учнів у рамках сучасної системи оцінювання в закладах середньої освіти застосовано метод опитування, у якому взяли участь 130 вчителів різних предметів базової школи (природознавства $(\mathrm{N}=18)$, хімії $(\mathrm{N}=20)$, біології $(\mathrm{N}=32)$, математики $(\mathrm{N}=35))$ та початкових класів (N=25). Серед них 95,62\% - жінки. Середній стаж роботи в школі становить 23,34 року (SD = 10,15), зокрема серед опитуваних учителів із стажем від 3 до 10 років $\mathrm{N}_{1}=18$; 
середній стаж 6,44 (SD = 2,31); від 11 до 20 років $\mathrm{N}_{2}=34$; середній стаж 16,90 (SD = 2,44); від 21 до 30 років $\mathrm{N}_{3}=52$; середній стаж $26,11(\mathrm{SD}=2,85)$; від 31 до 46 років: $\mathrm{N}_{4}=26$; середній стаж $37,72(\mathrm{SD}=4,81)$.

Запропонований респондентам опитувальник складався із 2 частин: (1) - блок запитань щодо особистих відомостей респондента - стать, спеціальність, педагогічний стаж; (2) - основна частина, яка містила запитання із 5-ма варіантами відповідей, спрямованих на визначення об'єктивності відображення у поточних та підсумкових оцінках рівня сформованості у здобувачів освіти знань, умінь, навичок, ставлення до предмету навчання, предметної компетентності, а також запитання, спрямовані на вивчення поглядів учителів на функції поточного оцінювання. Способи оцінювання (усний, письмовий, з використанням тестових технологій тощо) в анкеті не уточнювались. Опитування проводилось в очному форматі.

Респонденти висловлювали своє ставлення до пропонованих тверджень, оцінюючи їх за десятибальною шкалою, що дало можливість більш точно, ніж за п’ятибальною шкалою, виміряти ставлення вчителів до пропонованих аспектів. Такий підхід по суті є застосуванням методу ранжування респондентами оцінюваних структурних компонентів поточного та підсумкового оцінювання за порядковою шкалою.

Надійність анкети визначена за розрахунками коефіцієнта альфа Кронбаха, що становить 0,$876 ; \mathrm{F}(1,24)=7,32$. Опрацювання результатів експерименту проводилося з використанням програми IBM Statistica 10 із застосуванням статистичних методів (для визначення коефіцієнта конкордації, здійснення кластерного аналізу тощо).

Результати дослідження. Зважаючи на перехідний період модернізації системи оцінювання в рамках реформування шкільної освіти в Україні (неусталеність практики формувального оцінювання, різнотлумачення, термінологічні неузгодження тощо) та враховуючи відомості дослідження А.В. Гривко та Л.С. Ващенко (2021), яке засвідчило, що українські вчителі під час поточного оцінювання використовують, хоча і несистемно, технології формувального оцінювання, у своєму дослідженні (враховуючи нормативні положення Закону про освіту, Закону про загальну середню освіти та державних стандартів початкової та базової середньої освіти) під поточним оцінюванням ми розуміємо систему визначення та фіксування на основі загальних критеріїв оцінювання ступенів досягнення учнями конкретних результатів навчання (знань, умінь, навичок, ставлень та інших компонентів компетентностей) у процесі засвоєння ними окремих елементів освітньої програми під час вивчення змісту теми та оволодіння компетентностями відповідно до запланованих освітніх цілей і вимог державних стандартів освіти. Підсумкове оцінювання - співвіднесення результатів навчання учнів з обов'язковими результатами, визначеними державним стандартом, яке здійснюється після вивчення окремої теми (тематичне оцінювання); сукупності тем, розділу (семестрове, річне оцінювання); після здобуття початкової, базової середньої чи профільної середньої освіти (державна підсумкова атестація, зовнішнє незалежне оцінювання). Отже, якщо підсумкова оцінка $€$ показником загальних результатів навчання (спільні для всіх рівнів загальної середньої освіти результати навчання учнів в окремій освітній галузі, через які реалізується її компетентнісний потенціал), то поточні оцінки виражають досягнення учнями конкретних результатів навчання (результати досягнення освітніх цілей навчання в кожній освітній галузі, які деталізують змістові характеристики загальних результатів навчання за освітніми циклами). У аспекті такого розуміння показники поточного і підсумкового оцінювання мають корелювати, що залежить від можливості здійснення об’єктивного оцінювання навчальної діяльності учнів.

Погляди учителів на питання об’єктивності відображення рівня сформованості в учнів знань, умінь, ставлення до предмету навчання, компетентності під час поточного і підсумкового оцінювання, узагальнено на рис. 1-5. Думки респондентів виражались в оцінці ними рівня об’єктивності за 10-тибальною шкалою, рівень узгодженості думок визначено за коефіцієнтом конкордації (щодо поточного оцінювання - $W=0,705$, підсумкового оцінювання $-W=0,680$ : такі показники є достатніми і забезпечують можливість робити висновки за здобутими результатами). 
Рівень об'ективності оцінювання сформованості знань

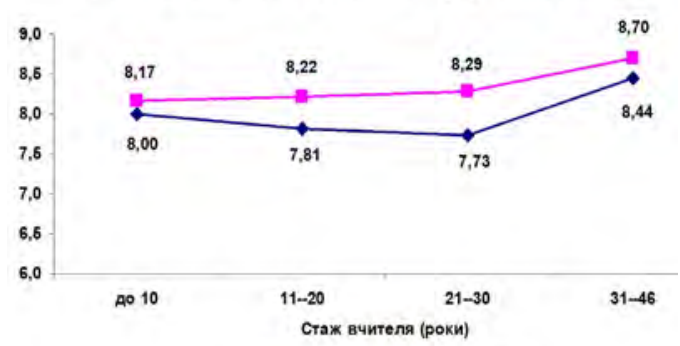

Рис. 1.

$\downarrow$ Поточна $\rightarrow$-Підсумкова

Рівень об'єктивності оцінювання сформованості умінь

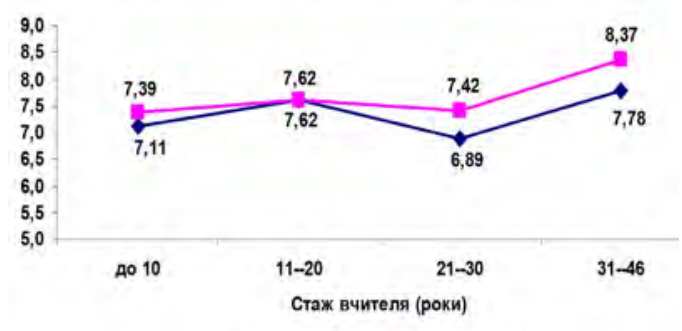

Рис. 3.

Рівень об'ективності оцінювання сформованості навичок

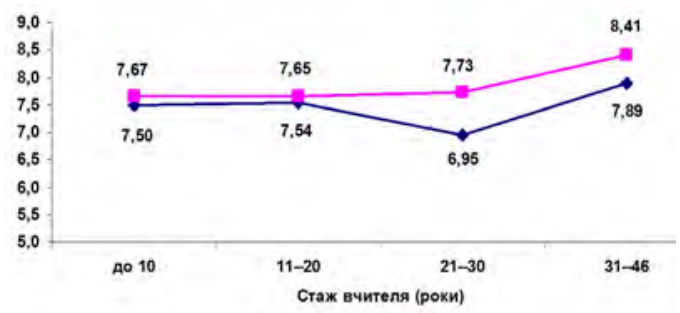

Рис. 2.

$\rightarrow$ Поточна $\rightarrow-$ Підсумкова

Рівень об'ективності оцінювання сформованості позитивного ставлення до предмету

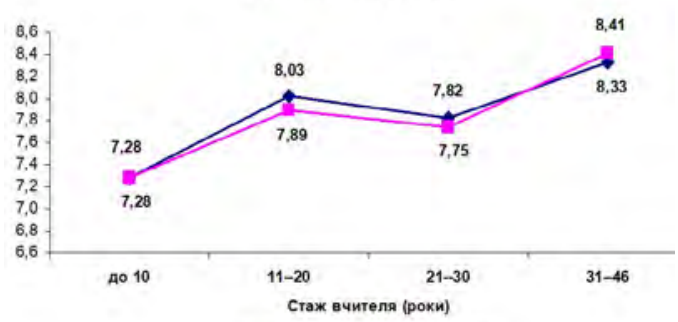

Рис. 4.

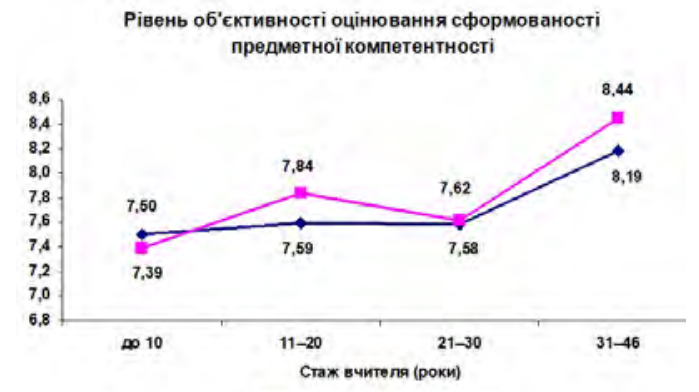

Рис. 5. $\rightarrow$ Поточна $-\approx-$ Підсумкова

Рис. 1-5. Рівень об’єктивності оцінки результатів навчання в умовах поточного і підсумкового оцінювання

Як бачимо, на думку вчителів, підсумкова оцінка (рис. 1-3, 5) більш об’єктивно відображує знання, уміння, навички та предметні компетентності школярів. Причому очевидною є залежність ставлення вчителів до об'єктивності оцінювання від їх стажу. Учителі з більшим досвідом роботи надають більшої значущості об’ єктивності оцінювання (оцінюють її вищим балом). Водночас рівень об'єктивності оцінки ставлення до предмету, на думку вчителів, фактично не залежить від виду оцінювання (рис. 4), а його значущість так само зростає зі збільшенням стажу педагогів.

Результати прямого опитування не завжди $є$ релевантними, що пов'язано з феноменом соціально очікуваних відповідей респондентів. Однак такі результати можуть розглядатися з позицій ідеального (від слова «ідея» - прим. авт.) бачення ними предмета опитування (переконань). Цікавим у цьому аспекті $є$ порівняння представлених результатів опитування вчителів із результатами дослідження співробітників відділу моніторингу та оцінювання якості загальної середньої 
освіти, яке проводилось на базі Хмельницького ліцею № 17. Одним із додаткових питань, яке вивчалось у рамках згаданого дослідження, було питання об'єктивності підсумкового оцінювання. Для цього учням 9-х класів (усього 87 осіб) було запропоновано оцінити свої реальні навчальні досягнення з української мови за 12-тибальною шкалою. Водночас учителі (3 особи) класів, які брали участь у дослідженні, зафіксували реальний (за своїми спостереженнями та власним переконанням), рівень навчальних досягнень учнів. Оцінки вчителів і учнів зіставлялися із річними оцінками, зафіксованими в журналі. Результати такого зіставлення представлено в табл. 1.

Таблиця 1.

Зіставлення уявлень вчителів та учнів про рівень навчальних досягнень із річними оцінками, зафіксованими в класних журналах

\begin{tabular}{|l|l|l|l|}
\hline Переконання & Відповідність оцінок \\
\hline $\begin{array}{l}\text { Категорія } \\
\text { респондентів }\end{array}$ & Підсумкова = Реальна & $\begin{array}{l}\text { Підсумкова < Реальна } \\
\text { (завищена) }\end{array}$ & $\begin{array}{l}\text { Підсумкова > Реальна } \\
\text { (занижена) }\end{array}$ \\
\hline Вчителі & $31 \%$ & $57,5 \%$ & $11,5 \%$ \\
\hline Учні & $32 \%$ & $17 \%$ & $51 \%$ \\
\hline
\end{tabular}

Як бачимо із таблиці, менше третини респондентів переконані в тому, що річна підсумкова оцінка повністю відповідає дійсності. На думку вчителів, ця оцінка є здебільшого завищеною для понад половини учнів (на 1 бал - для 36\% учнів, на 2 бали - для 16\%, на 3 бали - 4,5\%, 4 бали 1\%). Такі результати дещо суперечать думці про те, що підсумкова оцінка є об’єктивною.

Для уточнення інтерпретації результатів опитування здійснено кластерний аналіз, що дало можливість зробити висновок про структуру ментальних образів «поточна оцінка» та «підсумкова оцінка», які сформовані у педагогів з різним педагогічним стажем. На рис. 6 візуалізовано результати ієрархічного кластерного аналізу, який полягає в послідовному об'єднанні в різнорівневі кластери числових показників оцінюваних характеристик (оцінок об’єктивності певних результатів навчання учнів) на підгрунті їх кореляції (як міри подібності). Кластери (підмножини об’єктів статистичної сукупності, однорідних за своїми ознаками) утворюють деревовидну структуру, вершиною якої є характеристика, спільна для всіх параметрів. Відстань, на якій об’єднуються оцінювані характеристики, свідчить про ступінь їх подібності в узагальненому ментальному образі аналізованих понять.

Візуальний аналіз дендрограм показав, що у разі поточного оцінювання зв'язки між оцінюваними характеристиками є слабшими, ніж у разі підсумкового оцінювання, оскільки вони об’єднуються в кластери на більшій відстані (нижній поріг Евклідової відстані для характеристик поточного оцінювання у середньому становить 4,7, а для підсумкового оцінювання - 2,6; середня відстань від найбільш подібних до найменш подібної оцінюваної характеристики в разі поточного оцінювання становить 3, у разі підсумкового оцінювання - 1). Такі спостереження можуть свідчити про розуміння респондентами підсумкової оцінки як комплексного показника навчальних досягнень, а поточної - як показника окремих, хоча і пов’язаних між собою, результатів навчання.

Змістова інтерпретація кластерів дала змогу з’ясувати, що, на думку вчителів (незалежно від їхнього стажу), уміння і навички є найбільш подібними результатами навчання, які можна об'єднати в одну характеристику (на 7 із 8 дендрограм вони утворюють кластер на найменшій відстані (рис. 6)). Окрім іншого, це означає, що уміння й навички однаково об'єктивно відображаються як у поточній, так і в підсумковій оцінці. Різницею в поглядах опитаних учителів $\epsilon$ лише те, визначальною для усіх інших результатів навчання (здебільшого при підсумковому оцінюванні) чи залежною від них є об'єктивність оцінки умінь і навичок учнів (місце у структурі взаємопов’язаних результатів навчальної діяльності учнів).

Другий за частотністю кластер об’єднує такі результати навчання, як «ставлення» і «компетентність». Характеристика, яка здебільшого є відокремленою (за своїми ознаками) та не 
об’єднується в кластери з іншими характеристиками,- «знання», причому у разі підсумкового оцінювання така ситуація спостерігається на дендрограмах за результатами опитування усіх груп учителів (за педагогічним стажем роботи). Водночас, на думку вчителів, ця характеристика виявляється в діяльнісних результатах навчання - вміннях, навичках, компетентностях.

Стаж до 10 років
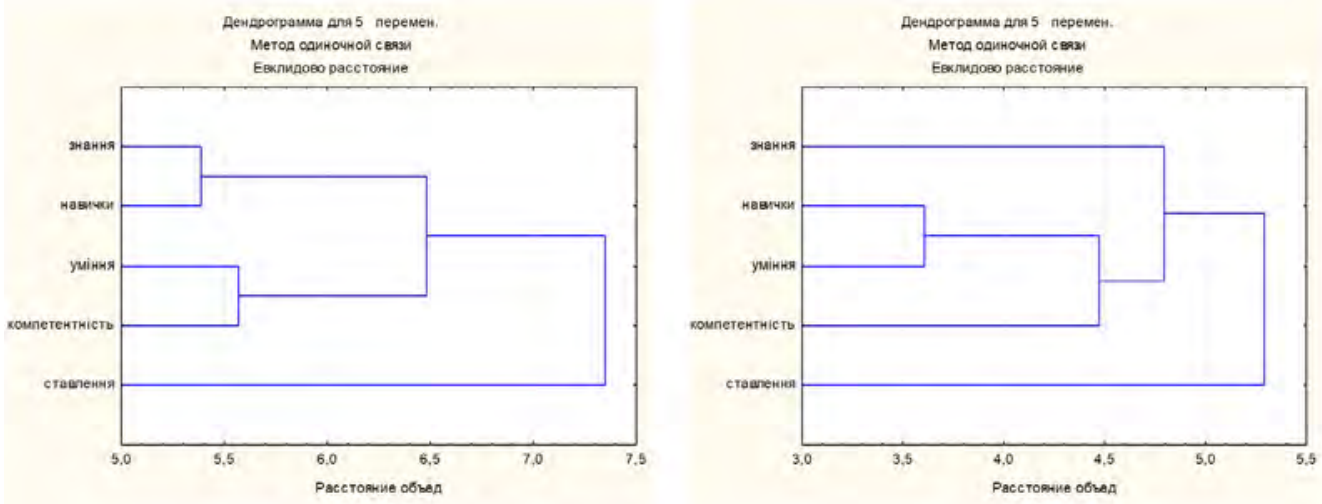

Стаж 11 - 20 років
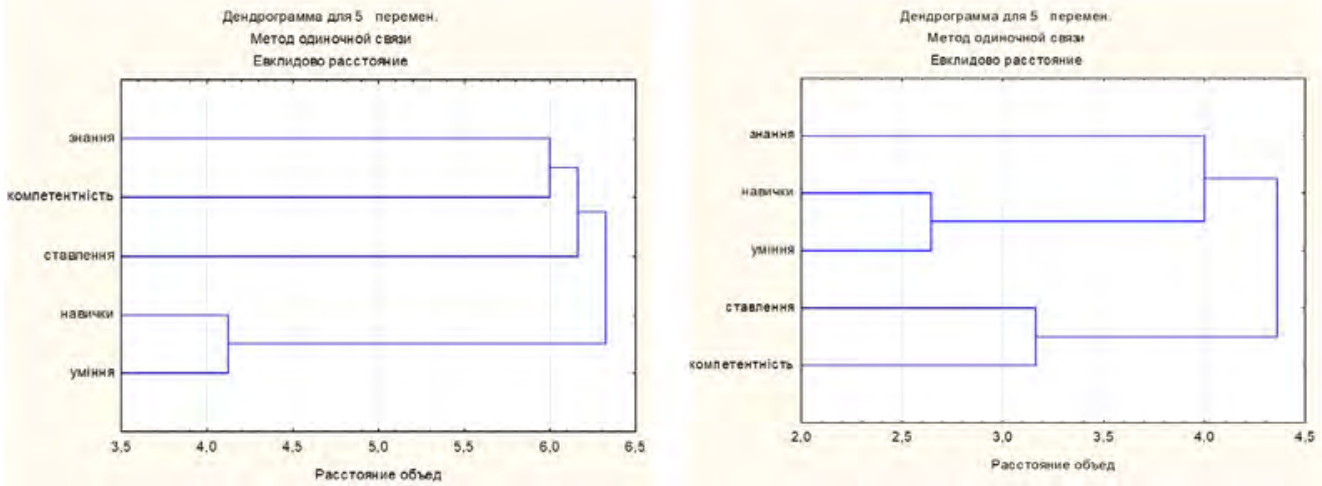

Стаж 21 - 30 років
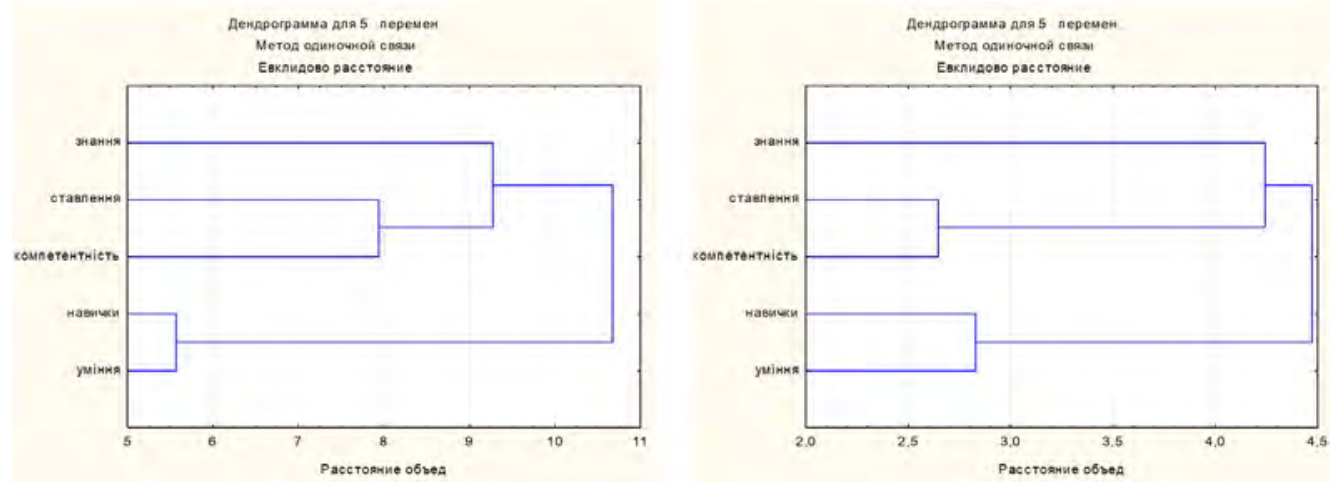
Стаж $31-46$ років
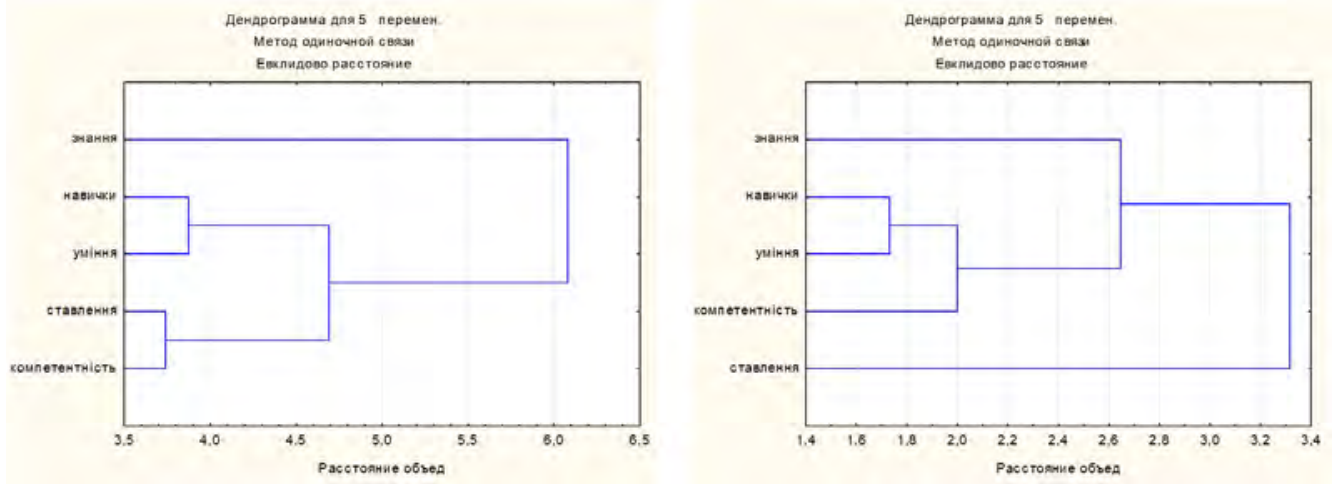

Рис. 6. Ментальний образ понять «поточна оцінка», «підсумкова оцінка»

\section{Висновки та перспективи подальших досліджень.}

1. Зі збільшенням педагогічного досвіду вчителів значення об'єктивності оцінки зростає для всіх аналізованих результатів навчання. Це може бути свідченням як зростання довіри до системи оцінювання, так і розуміння респондентами значення оцінки (розвиток діагностичної комепетентності вчителів). Доказом різного розуміння вчителями з різним педагогічним досвідом того, що оцінюється у процесі поточного і підсумкового оцінювання (визначення пріоритетності оцінюваних якостей у процесі виставлення оцінки), є різні моделі структури ментальних образів понять «поточна оцінка», «підсумкова оцінка» у респондентів відповідних груп (за стажем роботи).

2. Підсумкове оцінювання виглядає більш об’єктивним, ніж поточне для всіх досліджуваних характеристик і всіх груп вчителів, які брали участь у дослідженні. Такі результати, очевидно, свідчать про впевненість респондентів у можливості комплексно оцінити навчальні досягнення учнів відповідно до еталону (критеріїв оцінювання, вимог до обов'язкових результатів навчання) на етапі завершення певного навчального циклу (вивчення теми, розділу, за підсумками семестру, року тощо). Водночас розбіжності уявлень вчителів про об'єктивність підсумкової оцінки з результатами аналізу реальної ситуації оцінювання (теорії і практики) можуть свідчити про недосконалість чинної системи в аспекті знецінення значення оцінок та формування недовіри до документально фіксованих результатів навчання.

3. Поточне оцінювання, на думку вчителів, дає можливість оцінити об’єктивно результати навчання лише частково - більш відокремлено один від одного, у процесі формування кожного з них. У такому разі оцінка є показником незавершеної, продовжуваної дії та водночас не завжди $\epsilon$ результатом еталонного оцінювання, а ії об’єктивність залежить від ітеративності та регулярності спостережень і фіксування вчителем змін в урочній діяльності учнів, що в сучасних умовах організації навчання в закладах середньої освіти (кількість учнів у класі, організація зовнішніх умов самостійного виготовлення навчального продукту (виконання вправ і завдань) на уроці) $є$ сумнівною практикою. Тому підсумкова оцінка не може визначатися виключно як середнє арифметичне або мода з поточних оцінок, вона має відображати висновок вчителя про динаміку i прогрес у розвитку учня та водночас враховувати результати поточного та тематичного оцінювання. Недоліки об’єктивності поточного оцінювання можуть компенсуватися формувальним оцінюванням, спрямованим не на фіксування результатів, а на своєчасну допомогу учням у оволодінні ними змістом навчального матеріалу.

4. Визначальним для об’єктивності результатів як поточного, так підсумкового оцінювання, на думку вчителів, $є$ діяльнісний показник навчальних досягнень учнів - вміння та навички (рівень об’єктивності їх оцінювання визначає об'єктивність оцінювання засвоєних знань (готовності застосування їх) і сформованості компетентності (осмисленого застосування знань). 
Подальші напрями досліджень визначаються актуальністю експериментального вивчення методів і технологій забезпечення об'єктивності поточного оцінювання навчальних досягнень учнів у системі педагогічної діяльності вчителя в контексті сучасного етапу реформування системи загальної середньої освіти та у зв'язку із вивченням питання, як учителі використовують результати поточного оцінювання для прийняття рішень щодо подальших стратегій навчальної діяльності.

\section{Використані джерела}

[1] Болюбаш, Я.Я., Булах, I.Є., Мруга, М.Р., Філончук, І.В. (2007). Педагогічне оцінювання і тестування. Правила, стандарти, відповідальність. Майстер-клас, К., 272 с.

[2] Голубева, Э. А. (1993). Способности и индивидуальность. Прометей, М., 306 с.

[3] Гривко, А.В., Ващенко, Л.С. (2021). Поточне та формувальне оцінювання в базовій та старшій профільній школі. Український педагогічний журнал, 2, 72-83. DOI: 10.32405/2411-1317-2021-2-72-83

[4] Зыков, В. И. (1971). Познавательная деятельность учащихся со стойкой неуспеваемостьюв условиях работы экспериментальных классов. Психологические проблемы неуспеваемости школьников. Педагогика, М., 206-252.

[5] Ляшенко, О.І., Лукіна, Т.О., Жук, Ю.О., Ващенко, Л.С., Науменко, С.О., Гривко, А.В. (2014). Тестові технології оцінювання ключових і предметних компетентностей учнів основної і старшої школи. Монографія. Педагогічна думка, К., 200 с.

[6] Ляшенко, О.І., Жук, Ю.О., Ващенко, Л.С., Гривко, А.В., Науменко, С.О. (2017). Тестові технології оцінювання компетентностей учнів. Посібник. Видавничий дім «Сам», К., 128 с.

[7] Перовский, Е. И. (1960). Проверка знаний учащихся в средней школе. Акад. пед. наук РСФСР, М., 510 с.

[8] Петренко, В. Ф. (1986). Семантический анализ профессиональных стереотипов. Bопр. психологии, 3, 133-143.

[9] Реан, А. А. (1994). Психология педагогической деятельности. Удмурд. ун-т, Ижевск, 93 с.

[10] Gomez, M. (2017). Teachers' Assessment and grading Practices in upper secondary Science Classrooms in Sweden: The Teachers' and Students' Perspectives. Lund University. 170 p.

[11] Deneen, C.C., Fulmer, G.W., Brown, G.T.L., Tan, K., Leong, W.S., Tay, H.Y. (2019). Value, practice and proficiency: Teachers' complex relationship with assessment for learning. Teaching and Teacher Education, 80, 39-47.

[12] Lange, T. M. (2014). Interim assessment data: a case study on modifying instruction based on benchmark feedback: A Dissertation. Liberty University, Lynchburg, Virginia, 126 p.

[13] Pellegrino, J., Chudowsky, N., \& Glaser, R. (2001). Knowing What Students Know: The Science and Design of Educational Assessment. Washington, DC: NATIONAL ACADEMY PRESS, 379 p.

\section{References}

[1] Bolyubash, Ya. Ya., Bulax, I. Ye., Mruga, M. R., Filonchuk, I. V. (2007). Pedagogical assessment and testing. Rules, standards, responsibilities. Majster-klas, K., 272 c.

[2] Gomez, M. (2017). Teachers' Assessment and grading Practices in upper secondary Science Classrooms in Sweden: The Teachers' and Students' Perspectives. Lund University. 170 p.

[3] Deneen, C.C., Fulmer, G.W., Brown, G.T.L., Tan, K., Leong, W.S., Tay, H.Y. (2019). Value, practice and proficiency: Teachers' complex relationship with assessment for learning. Teaching and Teacher Education, 80, 39-47.

[4] Golubeva, E. A. (1993). Abilities and personality. Prometej, M., 306 c.

[5] Hryvko, A. V., Vashhenko, L. S. (2021). Current and formative assessment in basic and senior profile school. Ukrainian pedagogical journal, 2, 72-83. DOI: 10.32405/2411-1317-2021-2-72-83

[6] Lange, T. M. (2014). Interim assessment data: a case study on modifying instruction based on benchmark feedback: A Dissertation. Liberty University, Lynchburg, Virginia, 126 p.

[7] Lyashenko, O. I., Lukina, T. O., Zhuk, Yu. O., Vashhenko, L. S., Naumenko, S. O., Hryvko, A. V. (2014). Test technologies for assessing the key and subject competencies of primary and secondary school students. Monograph. Pedagogichna dumka, K., 200 c. 
[8] Lyashenko, O. I., Zhuk, Yu. O., Vashhenko, L. S., Hryvko, A. V., Naumenko, S. O. (2017). Test technologies for assessing student competencies. Manual. Vy`davny`chy`j dim «Sam», K., 128 c.

[9] Pellegrino, J., Chudowsky, N., \& Glaser, R. (2001). Knowing What Students Know: The Science and Design of Educational Assessment. Washington, DC: NATIONAL ACADEMY PRESS, 379 p.

[10] Perovskij, E. I. (1960). Testing the knowledge of students in high school. Akad. ped. nauk RSFSR, M., 510 c.

[11] Petrenko, V. F. (1986). Semantic analysis of professional stereotypes. Voprosy psihologii, 3, 133-143.

[12] Rean, A. A. (1994). Psychology of pedagogical activity. Udmurd. un-t, Izhevsk, 93 c.

[13] Zykov, V. I. (1971). Cognitive activity of students with persistent academic failure in the conditions of the experimental classes. Psychological problems of schoolchildren's academic failure. Pedagogika, M., 206-252.

Yurii Zhuk, D. Sc. (Pedagogy), Associate Professor, Head of the Monitoring and Assessment of the Education Quality Department of Institute of Pedagogy of the NAES of Ukraine, Kyiv, Ukraine.

Antonina Hryvko, PhD (Pedagogy), Senior Research Fellow, Senior Researcher at the Monitoring and Assessment of the Education Quality Department, Institute of Pedagogy of the NAES of Ukraine, Kyiv, Ukraine.

Lidiia Vashchenko, PhD (Pedagogy), Senior Researcher Fellow, Senior Researcher at the Monitoring and Assessment of the Education Quality Department, Institute of Pedagogy of the NAES of Ukraine, Kyiv, Ukraine.

\section{ON THE WAY OF MODERNIZATION OF THE EVALUATION SYSTEM: RESEARCH OF TEACHERS' PERCEPTION OF CURRENT AND FINAL ASSESSMENT IN THE SECONDARY SCHOOL}

The article considers the peculiarities of teachers' determination of the objectivity of the current and final assessment of the learning outcomes of secondary school students as the condition for choosing the strategy evaluation and control activities. Based on results of questionnaire data $(\mathrm{N}=103)$ with using statistical methods of analysis (calculation of the concordance coefficient, cluster analysis, etc.), authors generalized the value of objectivity of reflection of knowledge, skills, competencies, attitude to the subject in the current and final assessments for different groups of respondents, as well as models of the structure of mental images of terms current assessment and final assessment, which were developed by teachers with different work experience. It was found that the level of objectivity of each of the assessed learning outcomes is higher in the final assessment. At the same time, as teachers' pedagogical experience increases, so does the importance they give to the objectivity of all analyzed learning outcomes assessment. Comparison of the teachers' survey results with the results of the study, which compared the documented final (annual) and actual assessments (according to students' and teachers' survey, $\mathrm{N}=90$ ), showed differences between teachers' perceptions (as it should be) and the factual state of affairs (as it is) - less than third respondents are convinced that the annual final assessment is completely true.

The results of the cluster analysis revealed that the respondents understand the final assessment as a complex indicator of academic achievement, and the current - as an indicator of individual, albeit related, learning outcomes. The comparison of the constructed models allowed to generalize that, according to the respondents, the level of objectivity of abilities and skills assessment determines the objectivity of the assessment of acquired knowledge (readiness to apply them) and the formation of competence (meaningful application of knowledge).

Further research may be concerned with examining how teachers use the results of ongoing assessment to make decisions about further learning strategies in terms of competency-based learning.

Keywords: current assessment; final assessment; formative assessment; objectivity of assessment; learning outcomes. 